\title{
ANALYSIS AND PROSPECTS OF SEPARATE ENVIRONMENTAL PROTECTION SYSTEMS AT COAL MINING AND COAL PROCESSING ENTERPRISES OF UKRAINE
}

(C) O.A. Atamanyuk, PhD (LLC "Center for Ecology and Development of New Technologies", 01032, Kyiv, Leo Tolstoy st., 33, office 75, Ukraine), O.M. Kasimov, Doctor of Technical Sciences (State Enterprise "Ukrainian State Research Coal Chemistry Institute (UHIN)", 61023 Kharkov, Vesnina st., 7, Ukraine)

The article describes the organizational regional structure of industrial waste management in modern Ukraine, which will improve the efficiency of industrial waste management systems and industrial energy facilities in Ukraine. The structure of industrial waste management at different system levels, from the national to the level of an industrial enterprise, is described.

The data on the recommendations of the World Health Organization on the emissions of toxicants into the air and the data of the State Statistics Service of Ukraine on the content of the main pollutant gases in air emissions from stationary sources of Ukraine from 1990 to 2018 are presented.

The scheme of the negative impact on the environment of emissions of pollutants from stationary sources - production facilities of coal mining and coal processing is characterized. Comparative data on the indicators of the volumes of toxic waste generation at the enterprises of European countries and the heavy industry of Ukraine are given. It is shown that the main sources of the impact of coal processing enterprises and coal processing industries on all spheres of the environment are organized and unorganized dust and gas emissions, discharges of process wastewater and effluents from the surface and from the volumes of dumps and sludge collectors of coal processing plants.

As a result of comprehensive research by the authors, a number of coal dumps of concentrating factories in Eastern Ukraine have been studied, migration routes and concentration of rare and heavy metal compounds in the soil near coal dumps have been investigated. Rather stringent standards for the content of hazardous substances in industrial waste require special methods for neutralizing coal sludge before final disposal and / or disposal.of the raw materials used to obtain humic acids. The corresponding equations are given.

Keywords: coal sludge, coal preparation plants, coal dumps, sludge collectors, surface runoff, environmental pollution, emissions into the atmosphere, gaseous, liquid and solid toxicants.

Corresponding author O.M. Kasimov, e-mail:nto@ukhin.org.ua 